\title{
Effect of Different Sources and Levels of Sulphur on Safflower (Carthamus tinctorius L.)
}

\author{
V.U. Divya* \\ Department of Agronomy, Palli Siksha Bhavana, Visva-Bharati University, West Bengal, India \\ *Corresponding author
}

\section{A B S T R A C T}

Keywords

Sulphur, Safflower,

Zinc sulphate,

Elemental sulphur,

Single super

phosphate

Article Info

Accepted:

07 June 2019

Available Online:

10 July 2019
A field experiment was carried out during rabiseas on of 2016-17 at the Agricultural College Farm, Palli Siksha Bhavana (Institute of Agriculture), Visva-Bharati University, Sriniketan, Birbhum, West Bengal, India to study the effect of different sources and levels of sulphur on safflower. Experimental findings revealed that the use of different sources and levels of sulphur had significant effect in influencing the growth parameters, yield attributes. Among the levels and sources of Sulphur, $\mathrm{ZnSO}_{4} @ 40 \mathrm{~kg} \mathrm{~S} h a^{-1}$ resulted maximum growth parameters, yield attributes and yield of safflower. Application of zinc sulphate recorded $33.2 \%$ and $14.4 \%$ more seed yield over single super phosphate and elemental sulphur respectively.

\section{Introduction}

Safflower (Carthamus tinctorius L.) is an important rabi oilseed crop, grown in India since time immemorial predominantly in peninsular regions of the country. There are approximately 25 valid species in the genus, of which only $C$. tinctorius is the cultivated type, having $2 \mathrm{n}=24$ chromosomes. Though India has achieved a breakthrough in production of food grains mainly through wheat and rice, it is yet to achieve selfsufficiency in the yield and production of oil seeds and pulses. Safflower has a deep root system allowing the plant to utilize efficiently the nutrients that may not be available to small-grain crops (Tanaka and Merrill, 1998). Safflower plants are hardy in nature and have a capacity to withstand drought conditions hence it is grown successfully in rainfed condition (Knowles and Miller, 1965). It is becoming popular among the farmers because of its drought tolerance, short duration, deep tap root system, cultivable on all types of soil, well adaptation to dry and saline land conditions and commercial value. Dense root structure can improve soil tilth and porosity. Roots also add to organic matter, improving soil water holding capacity. The deficiency of secondary and micronutrients is wide spread in many parts of the country due to cultivation of high-yielding varieties, intensive 
agriculture and increasing use of sulphur-free fertilizers in large quantities with concomitant decrease in use of organic manures. In recent years, nutrient management is one of the critical inputs in achieving high productivity of safflower (Mundel et al., 2004). Sulphur is accumulated in plants in low concentrations compared to $\mathrm{N}$, but is an essential element as a constituent of proteins, cysteine-containing peptides such as glutathione, or numerous secondary metabolites (Scherer et al., 2008). For oilseed crop producers, sulphur containing fertilizer is important because oilseed crops require more sulphur than cereals. Sulphur is very crucial for the formation of sulphur containing amino acids and oil synthesis (Gangadhara et al., 1990). The biochemical oxidation of sulphur produces $\mathrm{H}_{2} \mathrm{SO}_{4}$ which decreases soil $\mathrm{pH}$ and solubilizes $\mathrm{CaCO}_{3}$ in alkaline calcareous soils to make more favorable soil conditions for plants growth including the availability of plant nutrients (Abdou, 2006). Erdal et al., (2006) reported that soil $\mathrm{pH}$ decreased with the application of $\mathrm{S}$, resulting in increases in nutrient concentration, plant nutrient uptake, chlorophyll concentration, root nodules and dry matter production

Hence, an attempt was made to study the effect of sulphur levels and sources on growth, yield and nutrient uptake parameters of safflower (Carthamus tinctorius L.) under irrigated condition at the agriculture farm, Palli Siksha Bhavana (Institute of Agriculture), Visva-Bharati, Sriniketan, Birbhum, West Bengal during the winter (November-December) season of 2016-2017.

\section{Materials and Methods}

This experiment has been conducted in the semi-arid, sub-humid, sub-tropical lateritic belt of West Bengal. Maximum and minimum temperature of the growing season varied from 27 to $41.8,6.4$ to 23.64 respectively and maximum and minimum $\mathrm{RH}$ of the growing season varied from 76 to $96.00,18$ to 72 respectively. Mean sunshine hours during growing season was $6.24 \mathrm{hrs}^{\mathrm{day}^{-1}}{ }^{-}$. Rainfall received during the entire growing season was $9.24 \mathrm{~mm}$. The experiment was laid out in a randomized block design. The treatments consisted of three sources and three levels of sulphur along with control plot. There were 10 treatments and each treatment was replicated thrice giving a total of 30 unit plots each measuring $3 \mathrm{~m} \quad \mathrm{x} 2 \mathrm{~m}$. The treatments consisted of three different sources of sulphur (viz.; Single super phosphate, elemental Sulphur and zinc sulphate) and three levels of sulphur (20, 40 and $60 \mathrm{~kg} \mathrm{~S} \mathrm{ha}{ }^{-1}$ ) and one control. Lime application was done to correct $\mathrm{pH}$ since the soil is acidic soil. The full dose of sulphur was applied from different sources of sulphur i.e. single super phosphate, zinc sulphate and elemental sulphur at 20, 40 and $60 \mathrm{~kg} \mathrm{~S} \mathrm{ha}^{-1}$ at the time of sowing as per treatment combinations. The recommended dose of nitrogen, phosphorus and potassium were applied at the rate of $40: 20: 20 \mathrm{~kg} \mathrm{~N}$, $\mathrm{P}_{2} \mathrm{O}_{5}$ and $\mathrm{K}_{2} \mathrm{O}$ per hectare in the form of urea, di ammonium phosphate and muriate of potash after taking into consideration of the contribution of $\mathrm{P}_{2} \mathrm{O}_{5}$ from single super phosphate. Urea was given in two split doses. First dose was given at the time of sowing and second dose was given one month after sowing. For recording various biometric observations, a sample size consisting of five plants from each treatment was selected randomly. From the samples, observations on various growth, morphological, yield and yield components were recorded at different stages of plant growth (30 DAS, 60 DAS, 90 DAS and at harvest).

\section{Results and Discussion}

At 30 DAS, on an average zinc sulphate recorded maximum $(9.3 \mathrm{~cm})$ plant height, maximum $\left(3.08 \mathrm{~g} \quad \mathrm{~m}^{-2}\right)$ dry matter 
accumulation followed by elemental sulphur and SSP. Application of zinc sulphate, $40 \mathrm{~kg} \mathrm{~S}$ $\mathrm{ha}^{-1}$ resulted highest $(10.4 \mathrm{~cm})$ plant height, highest dry matter accumulation $\left(3.54 \mathrm{~g} \mathrm{~m}^{-2}\right)$ followed by $60 \mathrm{~kg} \mathrm{Sha}^{-1}$ and $20 \mathrm{~kg} \mathrm{~S} \mathrm{ha}^{-1}$. At 60 DAS, on an average, zinc sulphate resulted highest $(24.3 \mathrm{~cm})$ plant height, highest number of branches (14.19), highest dry matter accumulation $\left(15.3 \mathrm{~g} \mathrm{~m}^{-2}\right)$ followed by elemental sulphur and SSP. Application of zinc sulphate, $40 \mathrm{~kg} \mathrm{~S} \mathrm{ha}^{-1}$ recorded highest $(35.5 \mathrm{~cm})$ plant height, highest $(15.83)$ number of branches, highest $\left(17.68 \mathrm{~g} \mathrm{~cm}^{-2}\right)$ dry matter accumulation followed by $60 \mathrm{~kg} \mathrm{~S}^{-1}$ and 20 $\mathrm{kg} \mathrm{S} \mathrm{ha}{ }^{-1}$. At 90 DAS, on an average, zinc sulphate resulted highest $(65.1 \mathrm{~cm})$ plant height, highest number of branches (14.3), highest dry matter accumulation (115.21 $\mathrm{g} \mathrm{m}^{-2}$ ) followed by elemental sulphur and SSP. Application of zinc sulphate, $40 \mathrm{~kg} \mathrm{~S} \mathrm{ha}{ }^{-1}$ recorded highest $(73.5 \mathrm{~cm})$ plant height, highest (15.9) number of branches, highest (133.2 $\left.\mathrm{g} \mathrm{cm}^{-2}\right)$ dry matter accumulation followed by $60 \mathrm{~kg} \mathrm{~S} h a^{-1}$ and $20 \mathrm{~kg} \mathrm{~S}^{-1}$. From 30-60 DAS, on an average, maximum $\left(0.41 \mathrm{~g} \mathrm{~m}^{-2}\right.$ day $\left.^{-1}\right)$ CGR observed with zinc sulphate followed by elemental sulphur and SSP. Among different sulphur levels, application of zinc sulphate, $40 \mathrm{~kg} \mathrm{~S} \mathrm{ha}^{-1}$ recorded maximum $\left(0.47 \mathrm{~g} \mathrm{~m}^{-2} \mathrm{day}^{-1}\right) \mathrm{CGR}$ followed by 60 and $20 \mathrm{~kg} \mathrm{~S}^{-1}$. From $60-90$ DAS, on an average, maximum $\left(0.77 \mathrm{~g} \mathrm{~m}^{-2}\right.$ day $^{-1}$ ) CGR observed with zinc sulphate followed by elemental sulphur and SSP. Among different sulphur levels, application of zinc sulphate, $40 \mathrm{~kg} \mathrm{~S}^{-1}$ recorded maximum $\left(0.89 \mathrm{~g} \mathrm{~m}^{-2} \mathrm{day}^{-1}\right)$ CGR followed by 60 and 20 $\mathrm{kg} \mathrm{S} \mathrm{ha}{ }^{-1}$. Increase in growth might be ascribed to better root formation due to sulphur, which in turn activated highest absorption of $\mathrm{N}, \mathrm{P}, \mathrm{K}$ and sulphur from soil and improved metabolic activity inside the plant (Kalaiyarasan et al., 2003). The fact was also supported by (Rao, 2009), (Debnath and Basu, 2013), (Singh and Thenua, 2016). Among levels of sulphur, $40 \mathrm{~kg} \mathrm{~S} \mathrm{ha}^{-1}$ was giving higher number of branches compared to other levels of sulphur. Nathan, (2015), Singh and Thenua, (2016), Shekhargouda et al., (1997) also reported similarly regarding levels of sulphur application.

In respect to, number of capitula per plant, on an average, maximum (17.03) number of capitula plant $^{-1}$ observed with zinc sulphate followed by elemental sulphur and SSP. Among different sulphur levels, application of zinc sulphate, $40 \mathrm{~kg} \mathrm{~S}^{-1}$ recorded maximum (21.9) capitula plant ${ }^{-1}$ followed by 60 and 20 $\mathrm{kg} \mathrm{S} \mathrm{ha-1}$.This result is in accordance with Rao, (1991), Singh and Thenua, 2016 and Nathan, (2015).

The data in relation to number of seeds capitulum $^{-1}$ showed that, on an average, maximum (17.03) number of capitula plant ${ }^{-1}$ observed with zinc sulphate followed by elemental sulphur and SSP. Among different sulphur levels, application of zinc sulphate, 40 $\mathrm{kg} \mathrm{S} \mathrm{ha}{ }^{-1}$ recorded maximum (23.43) seeds capitulum $^{-1}$ followed by 60 and $20 \mathrm{~kg} \mathrm{~S} \mathrm{ha}^{-1}$. Application of sulphur increased the plant growth by increasing the assimilating surface area. The highest photosynthates assimilation helped in net export of carbon to sink and thus increased the number of seeds capitulum ${ }^{-1}$ (Shekhawat and Shivay, 2008).

In respect to test weight, proved that, on an average, maximum $(30.67 \mathrm{~g})$ test weight observed with zinc sulphate followed by elemental sulphur and SSP. Among different sulphur levels, application of zinc sulphate, 40 $\mathrm{kg} \mathrm{S} \mathrm{ha}{ }^{-1}$ recorded maximum (31.7 g) test weight followed by 60 and $20 \mathrm{~kg} \mathrm{~S} \mathrm{ha}^{-1}$. This fact was also supported by Nathan (2015) regarding levels of sulphur.

In respect to, seed yield $\left(\mathrm{kg} \mathrm{ha}^{-1}\right)$, on an average, maximum $\left(730 \mathrm{~kg} \mathrm{ha}^{-1}\right)$ seed yield observed with zinc sulphate followed by elemental sulphur and SSP (Table 1-6). 


\begin{tabular}{|c|c|c|c|}
\hline \multicolumn{4}{|c|}{ Table.1 Effect of different sources and levels of sulphur on plant height of safflower } \\
\hline \multirow[t]{2}{*}{ Treatments } & \multicolumn{3}{|c|}{ Plant height (cm) } \\
\hline & 30DAS & 60DAS & 90DAS \\
\hline Control (no sulphur) & 6.5 & 11.3 & 44.6 \\
\hline SSP@20 kg S ha-1 & 7.1 & 14.8 & 54.5 \\
\hline SSP@ 40 kg S ha ${ }^{-1}$ & 7.5 & 16.6 & 57.9 \\
\hline SSP @60 kg S ha ${ }^{-1}$ & 7.3 & 15.6 & 55.4 \\
\hline Zinc sulphate @ 20 kg S ha ${ }^{-1}$ & 7.7 & 16.8 & 57.8 \\
\hline Zinc sulphate @ 40 Kg S ha ${ }^{-1}$ & 10.4 & 35.5 & 73.5 \\
\hline Zinc sulphate @ $60 \mathrm{~kg} \mathrm{~S} \mathrm{ha}^{-1}$ & 9.9 & 20.7 & 64.0 \\
\hline Elemental sulphur @ $20 \mathrm{~kg} \mathrm{~S} \mathrm{ha}^{-1}$ & 7.5 & 16.7 & 56.3 \\
\hline Elemental sulphur @ $40 \mathrm{~kg} \mathrm{~S} \mathrm{ha}^{-1}$ & 9.0 & 20.3 & 62.0 \\
\hline Elemental sulphur @ $60 \mathrm{~kg} \mathrm{~S} \mathrm{ha}^{-1}$ & 8.1 & 18.9 & 60.7 \\
\hline $\operatorname{S~Em~}( \pm)$ & 0.8 & 2.1 & 4.7 \\
\hline $\mathrm{CD}(p=0.05)$ & 2.3 & 6.3 & 14.0 \\
\hline
\end{tabular}

Table.2 Effect of different sources and levels of sulphur on number of branches of safflower at different days after sowing (DAS)

\begin{tabular}{|c|c|c|c|}
\hline \multirow[t]{2}{*}{ Treatments } & \multicolumn{3}{|c|}{ Number of branches per plant } \\
\hline & 60DAS & 90DAS & At harvest \\
\hline Control (no sulphur) & 7.33 & 7.5 & 7.20 \\
\hline SSP@20 kg S ha-1 & 7.73 & 7.9 & 11.6 \\
\hline SSP@ 40 kg S ha-1 & 11.1 & 11.2 & 12.9 \\
\hline SSP @ 60 kg S ha ${ }^{-1}$ & 7.9 & 8.1 & 12.1 \\
\hline Zinc sulphate@ 20 kg S ha ${ }^{-1}$ & 11.7 & 11.7 & 13.8 \\
\hline Zinc sulphate @ $40 \mathrm{Kg} \mathrm{S} \mathrm{ha}^{-1}$ & 15.8 & 15.9 & 21.9 \\
\hline Zinc sulphate @ $60 \mathrm{~kg} \mathrm{~S} \mathrm{ha}^{-1}$ & 15.1 & 15.3 & 15.4 \\
\hline Elemental sulphur @ $20 \mathrm{~kg} \mathrm{~S} \mathrm{ha}^{-1}$ & 9.6 & 9.9 & 12.5 \\
\hline Elemental sulphur @ $40 \mathrm{~kg} \mathrm{~S} \mathrm{ha}^{-1}$ & 14.8 & 14.9 & 14.13 \\
\hline Elemental sulphur @60 kg S ha ${ }^{-1}$ & 12.7 & 12.7 & 13.67 \\
\hline $\operatorname{S~Em~}( \pm)$ & 1.27 & 1.3 & 1.52 \\
\hline $\mathrm{CD}(p=0.05)$ & 3.78 & 3.7 & 4.52 \\
\hline
\end{tabular}

\begin{tabular}{|c|c|c|c|}
\hline \multicolumn{4}{|c|}{$\begin{array}{l}\text { Table.3 Effect of different sources and levels of sulphur on dry matter accumulation } \\
\text { of safflower at different days after sowing (DAS) }\end{array}$} \\
\hline \multirow[t]{2}{*}{ Treatments } & \multicolumn{3}{|c|}{ Dry matter accumulation $\left(\mathrm{gm}^{-2}\right)$} \\
\hline & 30DAS & 60DAS & 90 DAS \\
\hline Control (no sulphur) & 1.83 & 9.16 & 49.1 \\
\hline SSP @20 kg S ha-1 & 2.21 & 11.06 & 80.8 \\
\hline SSP@ 40 kg S ha ${ }^{-1}$ & 2.46 & 12.32 & 95.0 \\
\hline SSP @ $60 \mathrm{~kg} \mathrm{Sha}^{-1}$ & 2.27 & 11.34 & 92.2 \\
\hline Zinc sulphate@ 20 kg S ha ${ }^{-1}$ & 2.73 & 13.66 & 104.5 \\
\hline Zinc sulphate @ 40 Kg S ha-1 & 3.54 & 17.68 & 133.2 \\
\hline Zinc sulphate@60 kg S ha ${ }^{-1}$ & 2.98 & 14.55 & 109.7 \\
\hline Elemental sulphur @ $20 \mathrm{~kg} \mathrm{~S} \mathrm{ha}^{-1}$ & 2.39 & 11.97 & 93.9 \\
\hline Elemental sulphur @ $40 \mathrm{~kg} \mathrm{~S} \mathrm{ha}^{-1}$ & 2.87 & 14.37 & 108.1 \\
\hline Elemental sulphur@60 kg S ha ${ }^{-1}$ & 2.82 & 14.09 & 107.0 \\
\hline $\operatorname{S~Em~}( \pm)$ & 0.21 & 0.997 & 7.4 \\
\hline $\mathrm{CD}(p=0.05)$ & 0.62 & 2.962 & 21.9 \\
\hline
\end{tabular}




\begin{tabular}{|c|c|c|}
\hline \multicolumn{3}{|c|}{ Table.4 Effect of different sources and levels of sulphur on crop growth rate (CGR) of safflower } \\
\hline Treatments & CGR(30DAS-60DAS) $\left(\mathrm{g} \mathrm{m}^{-2} \mathrm{day}^{-1}\right)$ & CGR (60 DAS-90DAS) $\left(\mathrm{g} \mathrm{m}^{-2} \mathrm{day}^{-1}\right)$ \\
\hline Control (no sulphur) & 0.24 & 0.31 \\
\hline SSP @20 kg S ha ${ }^{-1}$ & 0.29 & 0.54 \\
\hline SSP@ 40 kg S ha-1 & 0.33 & 0.64 \\
\hline SSP @ $60 \mathrm{~kg} \mathrm{~S} \mathrm{ha}^{-1}$ & 0.30 & 0.62 \\
\hline Zinc sulphate@ 20 kg S ha ${ }^{-1}$ & 0.36 & 0.70 \\
\hline Zinc sulphate@ $40 \mathrm{Kg} \mathrm{S} \mathrm{ha}^{-1}$ & 0.47 & 0.89 \\
\hline Zinc sulphate@60 kg S ha ${ }^{-1}$ & 0.40 & 0.73 \\
\hline Elemental sulphur @ $20 \mathrm{~kg} \mathrm{~S} \mathrm{ha}^{-1}$ & 0.32 & 0.63 \\
\hline Elemental sulphur @ $40 \mathrm{~kg} \mathrm{~S} \mathrm{ha}^{-1}$ & 0.38 & 0.72 \\
\hline Elemental sulphur @ $60 \mathrm{~kg} \mathrm{~S} \mathrm{ha}^{-1}$ & 0.38 & 0.71 \\
\hline $\operatorname{S~Em~}( \pm)$ & 0.03 & 0.057 \\
\hline $\mathrm{CD}(p=0.05)$ & 0.08 & 0.17 \\
\hline
\end{tabular}

\begin{tabular}{|c|c|c|c|}
\hline \multicolumn{4}{|c|}{ Table.5 Effect of different sources and levels of sulphur on yield attributes of safflower } \\
\hline Treatments & Number of capitula plant ${ }^{-1}$ & $\begin{array}{l}\text { Number of seeds } \\
\text { capitulum }^{-1}\end{array}$ & Test weight $(\mathrm{g})$ \\
\hline Control (no sulphur) & 7.1 & 15.37 & 23.6 \\
\hline SSP @20 kg S ha-1 & 11.6 & 15.47 & 26.4 \\
\hline SSP@ 40 kg S ha ${ }^{-1}$ & 12.9 & 16.63 & 29.2 \\
\hline SSP @ $60 \mathrm{~kg} \mathrm{~S} \mathrm{ha}^{-1}$ & 12.1 & 16.60 & 27.9 \\
\hline Zincsulphate@20 kg S ha ${ }^{-1}$ & 13.8 & 18.60 & 29.5 \\
\hline Zinc sulphate@ $40 \mathrm{Kg} \mathrm{S} \mathrm{ha}^{-1}$ & 21.9 & 23.43 & 31.7 \\
\hline Zinc sulphate @ $60 \mathrm{~kg} \mathrm{~S} \mathrm{ha}^{-1}$ & 15.4 & 23.40 & 30.8 \\
\hline Elemental sulphur@ $20 \mathrm{~kg} \mathrm{~S} \mathrm{ha}^{-1}$ & 12.5 & 16.63 & 28.8 \\
\hline Elemental sulphur@ $40 \mathrm{~kg} \mathrm{~S} \mathrm{ha}^{-1}$ & 14.3 & 21.53 & 30.7 \\
\hline Elemental sulphur @60 kg S ha-1 & 14.1 & 20.57 & 30.4 \\
\hline S Em $( \pm)$ & 1.6 & 1.994 & 2.3 \\
\hline $\operatorname{CD}(p=0.05)$ & 4.6 & 5.924 & 6.8 \\
\hline
\end{tabular}

\begin{tabular}{|c|c|c|c|}
\hline Treatments & Seed yield $\left(\mathrm{Kg} \mathrm{ha}^{-1}\right)$ & Stover yield $\left(\mathrm{Kg} \mathrm{ha}^{-1}\right)$ & $\begin{array}{c}\text { Harvest } \\
\text { index }(\%)\end{array}$ \\
\hline Control (no sulphur) & 433.3 & 1590.0 & 20.7 \\
\hline SSP@20 kg S ha-1 & 523.3 & 1940.0 & 21.5 \\
\hline SSP@ 40 kg S ha-1 & 583.3 & 2150.0 & 21.4 \\
\hline SSP @ 60 kg S ha ${ }^{-1}$ & 536.7 & 2190.0 & 20.0 \\
\hline Zinc sulphate@ 20 kg S ha ${ }^{-1}$ & 646.7 & 2410.0 & 21.5 \\
\hline Zincsulphate@ 40 Kg S ha ${ }^{-1}$ & 836.7 & 2746.67 & 24.4 \\
\hline Zinc sulphate @ 60 kg S ha ${ }^{-1}$ & 706.7 & 2320.0 & 23.3 \\
\hline Elemental sulphur @ $20 \mathrm{~kg} \mathrm{~S} \mathrm{ha}^{-1}$ & 566.7 & 2280.0 & 19.9 \\
\hline Elemental sulphur @ 40 kg S ha $^{-1}$ & 680.0 & 2500.0 & 21.4 \\
\hline Elemental sulphur @ 60 kg S ha ${ }^{-1}$ & 666.7 & 2603.0 & 20.4 \\
\hline $\operatorname{S~Em~}( \pm)$ & 49.2 & 210.13 & 1.8 \\
\hline $\mathrm{CD}(p=0.05)$ & 146.2 & 624.27 & NS \\
\hline
\end{tabular}


Among different sulphur levels, application of zinc sulphate, $40 \mathrm{~kg} \mathrm{~S} \mathrm{ha}^{-1}$ recorded maximum $\left(836.7 \mathrm{~kg} \mathrm{ha}^{-1}\right)$ seed yield followed by 60 and $20 \mathrm{~kg} \mathrm{~S} \mathrm{ha}^{-1}$. This result is in accordance with Rao, (1991), Kumar et al., 2009 and Singh and Singh, 2014, regarding the result of levels of sulphur used.

Data in relation to stover yield proved that, on an average, maximum (3328 $\left.\mathrm{kg} \mathrm{ha}^{-1}\right)$ stover yield observed with elemental sulphur followed by zinc sulphate and SSP. Among different sulphur levels, application of zinc sulphate, $40 \mathrm{~kg} \mathrm{~S} \mathrm{ha}^{-1}$ recorded maximum $\left(2746 \mathrm{~kg} \mathrm{ha}^{-1}\right)$ stover yield followed by 60 and $20 \mathrm{~kg} \mathrm{Sha}^{-1}$

Maximum (23.06 \%) harvest index (\%) recorded with zinc sulphate followed by SSP and elemental sulphur. Among different sulphur levels, application of zinc sulphate, $40 \mathrm{~kg} \mathrm{~S} \mathrm{ha}{ }^{-1}$ recorded maximum $(24.4 \%)$ harvest index followed by 60 and $20 \mathrm{~kg} \mathrm{~S} \mathrm{ha}^{-}$ ${ }^{1}$. Gokhle, (2004) recorded that both 20 and $40 \mathrm{~kg} \mathrm{~S} \mathrm{ha}^{-1}$ produced the same effect. Similar result was obtained by Rao, (1991), Nathan, (2015), Singh and Thenua (2016).This might be due to adequate supply of sulphur helps in preventing floral abortion for potential establishments of larger number of filled seeds (Hocking et al., 1987).

It may be concluded that among the levels and sources of Sulphur, $\mathrm{ZnSO}_{4} @ 40 \mathrm{~kg} \mathrm{~S} \mathrm{ha}$ ${ }^{1}$ resulted maximum growth parameters, yield attributes and yield of safflower while in case of sulphur levels, zinc sulphate fertilizer, 40 $\mathrm{kg} \mathrm{S} \mathrm{ha}{ }^{-1}$ was reported superior over $60 \mathrm{~kg} \mathrm{~S}$ $\mathrm{ha}^{-1}$ and $20 \mathrm{~kg} \mathrm{Sha}^{-1}$, respectively

\section{Acknowledgements}

I am glad to convey my deep sense of gratitude and respect to Dr. N. C. Sarkar, Assistant Professor of Agronomy, Palli Siksha Bhavana, Visva-Bharati and Chairman of my advisory committee for his proper and effective guidance.

I express my deep sense to the members of the Advisory Committee Dr. B. Duary Associate Professor of the Department of Agronomy, Dr. P. Ghosh Assistant Professor of Department of a Department of Agronomy, Prof. G. K. Ghosh, Professor of the Department of Soil Science and Agricultural Chemistry, Dr. Kadar Ali Sarkar, Department of EES, Palli Siksha Bhavana for their kind help and valuable suggestions throughout the course of investigation.

I bestow my sincere gratitude to Prof. Ashish Chatterjee, Principal, Palli Siksha Bhavana and Prof. A. K. Barik, Head, Department of Agronomy (in the year 2016-18) for their cordial support and facilities provided for the successful completion of the experiment. I acknowledge my indebtedness to Prof. B. K. Saren, Dr. S.K. Maity, Dr. G. C. Malik, Dr. K. Paramanik, Dr. M. Banerjee, of the Department of Agronomy for their cooperation at various stages of the study. I also record my thanks to the staff members of the Agronomy Department, Agronomy and Soil Science Laboratory, Principal office of Palli Siksha Bhavana.

I must acknowledge Dr. Anup Kumar Das, Farm Manager and other staff members of PSB Agricultural Farm for their generous help and assistance during the entire period of field experiment.

\section{References}

Abdou, A.S. (2006). Effect of applied elemental sulfur and sulfur-oxidizing bacteria (Parococcus versutus) into calcareous sandy soils on the availability of native and applied phosphorus and some micronutrients. In: $18^{\text {th }}$ World Congress of Soil Science, 
July 9-15, 2006, Philadelphia, Pennsylvania, USA.

Debnath, S. and Basu, A.K. (2013). Effect of sulphur on seed yield and oil content in safflower. Journal ofCrop and Weed, 9(2): 113-114.

Erdal, I., Kepenek, K., and Kizilgoz, I. (2006). Effect of elemental sulphur and sulphur containing waste on the iron nutrition of strawberry plants grown in a calcareous soil. Biological Agriculture and Horticulture, 23: 263-272.

Gangadhara, G.A., Manjunathaiah, H.M. and Satyanarayana, T. (1990). Effect of sulphur on yield, oil content of sunflower and uptake of micronutrients by plants. Journal of the Indian Society of Soil Science, 38: 692-695.

Gokhle, K. (2004). Phosphorus and Sulphur management in Safflower (Carthamus tinctorius L.) (Master's thesis). Department Of Agronomy, Agricultural College, Bapatla, Acharya N. G. Ranga Agricultural University, Rajendranagar, Hyderabad - 500 030, India.

Hocking, P., Randall, P.J. and Pinkerton, A. (1987). Sulphur nutrition of sunflower (Helianthus annuus L.) as effected by $\mathrm{N}$ supply: Effects on vegetative growth, the development of yield components and seed yield and quality. Field CropsResearch, 16: 157-175.

Kalaiyarasan, C., Vaiyapuri, V. and Sriramachandrasekharan, M. V. (2007). Effect of sulphur sources and levels on the nutrient uptake, crop quality and SUE in groundnut. Journal of Interacademicia, 11(1): 55-58.

Knowles, P.K. and Miller, M.D. (1965). Safflower circular 632 California Agricultural Experimental station. California University, Davis, California, USA.

Kumar, R. (2009). Influence of sulphur and boron on growth and yield of sunflower (Helianthus annuus L.) (Master's thesis) Department of Agronomy, College of Agriculture, Acharya N. G. Ranga Agricultural University, Rajendranagar, Hyderabad-500 030, India.

Mundel, H.H., Morrison, R.J., Blackshaw, R.E. and Roth, B. (2004). Safflower Production on the Canadian Prairies: Revisited in 2004. Agriculture Canadian Research Station. Lethbridge, Alberta T1J 4B1, 11, 19, 23. Available from http://res2.agr.ca/lethbridge/safflo/part1 _e.htm.2004.

Nathan, R. (2015). Nitrogen and sulphur studies in spineless safflower variety under irrigated condition (master's thesis) Department of Agronomy, College of Agriculture, Telangana State Agricultural University, Rajendranagar, Hyderabad - 500 030, India.

Rao, D.V. (1991). Effect of phosphorus and Sulphur on nutrient uptake, yield and oil content of Safflower (Carthamus tinctorius Var. Manjira) (Master's thesis). Department of Soil Science and Agricultural Chemistry, College of Agriculture, Andhra Pradesh Agricultural University, Rajendranagar, Hyderabad-500 030, India.

Scherer, H.W., Pacyna, S., Spoth, K.R. and Schulz, M. (2008). Low levels of ferredoxin, ATP, and leghemoglobin contribute to limited N2 -fixation of peas (Pisum sativum L.) and alfalfa (Medicago sativa L.) under S deficiency conditions. Biology and Fertility of Soils, 44: 909-916.

Shekhargouda, Ravi Hunje, Biradar Patil, N.K. and Manjappa, K. (1997). Effect of sulphur and zinc on the growth and yield of safflower (Carthamus tinctorius L.). Karnataka Journal of Agricultural Science, 10(3): 766-771.

Shekhawat, K. and Shivay, Y.S. (2008). Effect of nitrogen sources, sulphur and boron levels on productivity, nutrient 
uptake and quality of sunflower (Helianthus annuus). Indian Journal of Agronomy, 53(2): 129-134.

Singh, R.K. and Singh, A.K. (2014).Effect of nitrogen, phosphorus and sulphur fertilization on productivity, nutrientuse efficiency and economics. Indian Journal of Agronomy, 58(4): 583-587.

Singh, S. B., and Thenua, O.V. (2016). Effects of Phosphorus and Sulphur
Fertilization on yield And NPS uptake by mustard (Brassica juncea L.). An International Journal Society for Scientific Development, 11(1): 80-83.

Tanaka, D.L. and Merrill, S.D. (1998). Deeprooted safflower cuts fertilizers losses. Agriculture Research Management (April). p. 17.

\section{How to cite this article:}

Divya, V.U. 2019. Effect of Different Sources and Levels of Sulphur on Safflower (Carthamus tinctorius L.). Int.J.Curr.Microbiol.App.Sci. 8(07): 757-764. doi: https://doi.org/10.20546/ijcmas.2019.807.091 